\title{
CLVIII Aniversário do Municipio de Rezende
}

C omemorou-se em setembro p.p. o CLVIII aniversário do Municipio de Rezende. Por ocasião dos festejos o Dr. Waldyr dos SAntos, Diretor da Divisão de Pessoal do D.A.S.P., convidado pelo Prefeito AugusTo DE CarvalHo, por ser filho dêsse Municipio, proferiu a oração oficial que passamos a transcrever:

«A data de hoje evoca, naturalmente, o esfôrço e a tenacidade dos que construiram Rezende. Não terão logrado, talvez, realizar, em tôda plenitude, o progresso que sonharam criar, ao plantarem aqui as primeiras sementes do antigo Povoado de Nossa Senhora da Conceição do Campo Alegre da Paraíba Nova.

No Brasil colonial, a estrutura econômica e social do país não era, todavia, de molde a propiciar o desenvolvimento de grandes comunidades progressistas, onde não se apresentasse a riqueza fácil à conquista e exploração dos senhores ide outrora.

Enquanto o ouro faiscou aos olhos do ambicioso dominador, o antigo povoado foi-se transformando num centro de convergências de interêsses e empreendimentos que marcaram, sem dúvida, o ponto culminante mas fugaz do seu prestígio colonial.

Esgotadas as riquezas, acalmada a sêde do ouro que então grassava nos espíritos, o Povoado de Nossa Senhora da Conceição do Campo Alegre passou a conhecer uma vida mais pacata e lenta, como que em harmonia com a paisagem que ainda hoje o cerca e o encima.

Partiram os forasteiros, aventureiros, o irrequieto exército dos desbravadores e garimpeiros. Aqui permaneceram os que se afeiçoaram à terra e nela quiseram deixar a marca da inteligência e de um trabalho nem sempre dadivosamente recompensado. Deixaram-se mais dominar pela belenza da paisagem, do que pelo brilho e o encanto da pepita.

Nasceu daí, certamente, a nossa inconfundivel vocação telúrica, como nasceram também dêsse deslocamento de interêsses, as bases de uma nova estrutura econômica, que foi buscar no cultivo do solo e na criação de rebanhos as fontes que ainda enriquecem e propulsionam a vida do nosso rincão.

O plantio do café mostrou se bem cêdo favorável e cheio de possibilidades econômicas, que asseguraram inclusive a sua extensão e outras províncias, como Minas e São Paulo. Rezende conhecerá, nessa etapa, os grandes dias de uma comunidade em vigorosa expansão de crescimento e progresso. Bafejada pelos governantes, que a elevam, sucessivamente, à categoria de vila, em 1801, e, depois, de cidade, em 1848, nosso municipio entrega-se aos labôres agrícolas e pastorís consolidando assim uma vocação que parecia brotar da própria terra. 
Não durará muito êsse episódio da cidade desenvolvendo-se a passos rápidos e firmes. O destino das cidades, no Brasil de hoje como no de ontem, tem sido sempre um destino ameaçado, de dificuldades, um destino quase sem horizonte. Vieram as crises, em consequiência, - crise da agricultura empobrecida, crise do braço, com a abolição dos escravos. E em breve seria o próprio regime que entraria em crise, incapaz e pequeno diante das imensas possibilidades de progresso e desenvolvimento do país.

Mas reformar hábitos, impor novos rumos e concepções, não é tarefa que se improvise ou frutifique em décadas apenas. A República não conseguiu ainda vivificar, em todo território nacional, todos êsses órgãos, em sua maioria, amorfos, isolados, apagados, que são os municipios brasileiros.

Desassistidos, incapazes de prover por êles mesmos as necessidades ele- mentares de energia, transporte e educação necessidades que o progresso dos séculos impôs nossos municipios guardam ainda em sua fisionomia arquitetônica, cultural e econômica, muitos daqueles traços com que surgiram na Colônia e no Império.

Rezende não poderia fugir a êsse quadro, que só a ciência e a técnica poderão corrigir e alterar, a serviço do povo e do desenvolvimento nacional. Entregue às atividades agricolas, à pecuária, à silvicultura, suas indústrias aparecem apenas como fruto de iniciativas carojosas e esparsas, carecendo de maior impeto e amplitude.

Foram e são muitos os pioneiros que lutaram, com trabalho e idealismo, para que nossa cidade consiga em definitivo, uma posição de destaque, dentro do quadro do desenvolvimento nacional. Homens do campo e da rua, simples operários ou detentores de títulos, todos se empenharam e se empenham pelo progresso que faça de Resende um município rico e próspero capaz de melhor contribuir para o engrandecimento do país.

Trabalho, idealismo e inteligência são, de resto, um traço lisongeiro da nossa gente, que aqui tem visto nascer homens ilustres, cujas personalidades se projetaram, para honra nossa, no cenário cultural do Estado ou do Brasil.

Todos souberam amar e dignificar esta terra, qualquer que fôsse o des* tino que os levou a paragens diferentes ou de elevadas posições, - os que tiveram Resende por berço natal, os que dela fizeram sua terra adotiva.

Luiz Pistarini, Ezequiel Freire, João Maia, Pereira Barreto, Clemente Ferreira, Oliveira Botelho, Eduardo Cotrim, e muitos outros, são nomes que recordamos com saudade e orgulho.

A dedicação das professôras Maria Alice, Bernarda Brandão do Vale, D. Efigênia, Maria Augusta Dinorah Freire, D. Antonina e Dulce Chaves, abre, para muitas gerações, o caminho da formação intelectual e social.

Ao transcurso de mais um aniversário da fundação da nossa cidade, sejam-lhes, pois, tributada a homenagem da nossa sincera evocação e sentido respeito. Ao fazê-lo, estamos certos de que o esfôrço e o idealismo que os inspiraram e inspiram, não se desperdiçarão no tempo. $\mathrm{O}$ exemplo dêles conduzirá Resende a novos estágios de organização e desenvolvimento.

Haveremos de fundar aqui o pequeno e próspero celeiro que alimentará indústrias e empreendimentos indispensáveis ao bem estar do País. Não sre- 
mos apenas invejados pelo feliz privilégio de possuirmos essas montanhas, êsse clima, essa vegetação, em cujo seio muitos vêm encontrar o repouso de atividades e de labor urbano. E nem apenas seremos lembrados como sede dessa extraordinária Academia Militar que tantos serviços tem prestado à Juventude do país desejosa de colocar-se a serviço da paz e da guerra, em defesa da Pátria.

Com sua agricultura, sua indústria, suas escolas, seus artistas, seus líderes e operários, com sua gente, Rezende construirá a cidade do trabalho e do progresso.

Honrado com o convite do dinâmico Prefeito Augusto de Carvalho para saudá-la em sua festa de aniversário, permitam-se concluir estas palavras com um voto de prosperidade e felicidade a quantos permanecem fiéis à nossa terra, concorrendo, de qualquer maneira, para a grandeza e o prestígio de Resende». 